\title{
KOMPETENSI DAN PERSPEKTIF FEMININ DALAM AUDIT
}

\author{
Yosevin Karnawati \\ Program Studi Akuntansi Fakultas Ekonomi dan Bisnis Universitas Esa Unggul \\ Jalan Arjuna Utara No 9 Kebon Jeruk Jakarta 11510 \\ yosevin.karnawati@esaunggul.ac.id
}

\begin{abstract}
Audit quality is all posibilities (auditor) where the auditor when auditing the financial statements can find what is happening in the client's accounting system and report it in audited financial statements. The audit must be carried out by one or more people who have sufficient expertise and technical training. The gender factor is an individual characteristic that is brought for within a person that is brought along and self perception is related to the way in which information is collected and prepared, thus affecting the quality of the resulting audit. This study tries to analyze competence and associate gender with audit quality. The subject in this study were auditors who worked at Kantor Akuntan Publik (KAP) in West Jakarta. Data collections uses purposive sampling with the criteria of auditors who have worked at least one years in KAP. The design of this study is causality or causation, using multiple linier regression analysis tools. The result showed that audit knowledge has a positive affect on audit quality but feminine personality negatively affects audit quality. While work experience and masculine personality has no effect to audit quality. This research to produces audit quality that is produced from audit knowledge while audit knowledge will increase accountability so that it will improve the quality of work results. On the other hand aggressive, emotional and illogical attitudes possessed by feminine personalities would otherwise lose audit quality.
\end{abstract}

Keywords: audit knowledge, work experience, gender, feminine, masculine, audit quality

\begin{abstract}
Abstrak
Kualitas audit merupakan segala kemungkinan (probability) dimana auditor pada saat mengaudit laporan keuangan klien dapat menemukan pelanggaran yang terjadi dalam sistem akuntansi klien dan melaporkannya dalam laporan keuangan auditan. Audit harus dilaksanakan oleh seorang atau lebih yang memiliki keahlian dan pelatihan teknis yang cukup. Faktor gender merupakan karakteristik individu yang berasal dari dalam diri seseorang yang membawa serta persepsi diri terkait dengan cara di mana informasi dikumpulkan dan diproses, sehingga berpengaruh terhadap kualitas audit yang dihasilkan. Penelitian ini bertujuan untuk menganalisis pengaruh kompetensi dan orientasi tipe peran gender yang terhadap kualitas audit. Subyek dalam penelitian ini adalah auditor yang bekerja pada Kantor Akuntan Publik (KAP) di Jakarta Barat. Pengumpulan data menggunakan purposive sampling dengan kriteria auditor yang telah bekerja selama minimal satu tahun pada KAP. Desain penelitian ini adalah kausalitas atau sebab akibat, dengan menggunakan alat analisis regresi linier berganda. Hasil penelitian menunjukkan bahwa pengetahuan audit berpengaruh positif terhadap kualitas audit, namun kepribadian feminin berpengaruh negatif terhadap kualitas audit. Sedangkan pengalaman kerja dan kepribadian maskulin tidak berpengaruh terhadap kualitas audit. Penelitian ini menyimpulkan bahwa kualitas audit dihasilkan dari pengetahuan audit dimana pengetahuan audit akan memperkuat akuntabilitas sehingga akan meningkatkan kualitas hasil kerja. Di sisi lain sikap agresif, emosional dan tidak logis yang dimiliki oleh kepribadian feminin justru akan menurunkan kualitas audit
\end{abstract}

Kata kunci: Pengetahuan audit, pengalaman kerja, gender, feminine, maskulin, kualitas audit. 


\section{Pendahuluan}

Untuk menghasilkan laporan keuangan yang baik, maka kualitas audit perlu diperhatikan. DeAngelo (1981) mendefinisikan kualitas audit sebagai probabilitas dimana seorang auditor menemukan dan melaporkan tentang adanya suatu pelanggaran dalam sistem akuntansi kliennya. Probabilitas penemuan suatu pelanggaran tergantung pada kemampuan auditor dan tingkat independensi auditor.

Kualitas audit dapat dicapai jika auditor memiliki kompetensi yang baik. Kompetensi tersebut terdiri dari dua dimensi yaitu pengalaman dan pengetahuan. Auditor sebagai ujung tombak pelaksanaan tugas audit memang harus senantiasa meningkatkan pengetahuan yang telah dimiliki agar penerapan pengetahuan dapat maksimal dalam praktiknya. Penerapan pengetahuan yang maksimal tentunya akan sejalan dengan semakin bertambahnya pengalaman yang dimiliki. Kompetensi juga dapat diperoleh melalui pendidikan dan pengalamannya dalam mengaudit klien (Haryono, 2001). Tingkat pengetahuan yang dimiliki auditor merupakan hal yang sangat penting yang dapat mempengaruhi auditor dalam mengambil keputusan. Pengetahuan merupakan salah satu kunci keefektifan kerja (Herawaty dan Sutanto, 2009). Dengan tingkat pengetahuan yang tinggi yang dimiliki oleh seorang auditor, auditor tidak hanya akan bisa menyelesaikan sebuah pekerjaan audit secara efektif tetapi juga akan mempunyai pandangan yang lebih luas mengenai berbagai hal. Auditor yang memiliki tingkat pengetahuan yang tinggi dapat mendeteksi sebuah kesalahan.

Pengalaman juga memberikan dampak pada setiap keputusan yang diambil dalam pelaksanaan audit sehingga diharapkan setiap keputusan yang diambil merupakan keputusan yang tepat. Hal tersebut mengindikasikan bahwa semakin lama masa kerja yang dimiliki auditor maka akan semakin baik pula kualitas audit yang dihasilkan. pada penelitian sebelumnya yang dilakukan oleh Saripudin et al. (2012), menunjukkan bahwa pengalaman kerja berpengaruh positif dan signifikan baik secara parsial maupun simultan, sementara penelitian yang dilakukan oleh Harvita dan Pramudji (2012), menunjukkan bahwa pengalaman audit tidak mempunyai pengaruh yang signifikan terhadap kualitas hasil audit. Penelitian Bawono et al. (2010) tentang pengalaman kerja memberikan hasil bahwa tidak terdapat pengaruh pengalaman kerja terhadap kualitas audit, sementara dari penelitian Sukriah et al. (2009), menyatakan bahwa pengalaman kerja, obyektifitas, dan kompetensi berpengaruh terhadap kualitas audit.

Menurut Jamilah dan Fanani (2007), gender diduga menjadi salah satu faktor level individu yang turut mempengaruhi kualitas hasil kerja auditor internal seiring dengan terjadinya perubahan pada kompleksitas tugas. Temuan riset literatur psikologis kognitif dan pemasaran juga menyebutkan bahwa wanita diduga lebih efisien dan efektif dalam memproses informasi saat adanya komplesitas tugas dalam pengambilan keputusan dibandingkan dengan pria.

Biasanya gender dan jenis kelamin biologis dibedakan secara mendasar menjadi dua yaitu laki-laki dan perempuan yang mutlak dimiliki manusia ketika lahir, sedangkan Mikkola (2005) mendefinisikan gender sebagai suatu gambaran sifat, sikap dan perilaku pada lakilaki dan perempuan. Menurut Bem (1974), terdapat dua model peran gender dalam menjelaskan mengenai maskulintas dan feminitas. Model tradisional menyebutkan bahwa maskulinitas, dan feminitas merupakan titik-titik yang berlawanan pada sebuah kontinum yang bipolar. Meyers-Levy (1986), menduga bahwa gender berpengaruh secara signifikan terkait dengan cara dimana informasi dikumpulkan dan diolah sehingga dapat mempengaruhi pengambilan keputusan.

Penelitian ini bertujuan untuk menganalisis faktor pengetahuan audit, pengalaman dan gender terhadap kualitas audit. Dalam hal ini faktor gender akan diidentifikasi secara psikologis sehingga menghasilkan gambaran sifat feminin atau maskulin dalam diri auditor.

\section{Tinjauan Pustaka \\ Audit}

Menurut Arens dan James (2000), audit adalah kegiatan mengumpulkan dan mengevaluasi dari bukti-bukti mengenai informasi untuk menentukan dan melaporkan 
tingkat kesesuaian antara informasi dengan kriteria yang telah ditetapkan. Proses audit harus dilakukan oleh orang yang kompeten dan independen.

Menurut The American Accounting Association's Committee on Basic Auditing Concept audit merupakan suatu proses yang sistematis untuk memperoleh dan mengevaluasi bukti secara obyektif mengenai pernyataan tentang kegiatan dan kejadian ekonomi dengan tujuan untuk menetapkan tingkat kesesuaian antara pernyataan-pernyataan tersebut dengan kriteria yang telah ditetapkan serta menyampaikan hasilnya kepada pemakai yang berkepentingan.

\section{Kualitas Audit}

DeAngelo

(1981) mendefinisikan

kualitas audit sebagai probabilitas dimana seorang auditor menemukan dan melaporkan tentang adanya suatu pelanggaran dalam sistem akuntansi kliennya. Hasil penelitiannya menunjukkan bahwa KAP yang besar akan berusaha untuk menyajikan kualitas audit yang lebih besar dibandingkan dengan KAP yang kecil.

Berikut adalah konsep atribut kualitas menurut Widagdo et al. (2002), Alim et al. (2007) yang relevan dengan audit pemerintah :

a. Responsif atas kebutuhan klien. Klien berharap menerima lebih banyak bukan hanya opini audit klien saja, tetapi juga ingin mendapatkan keuntungan dari keahlian dan pengetahuan auditor serta nasehat tanpa diminta.

b. Taat pada standar umum Kredibilitas auditor bergantung pada: a) Kemungkinan auditor mendeteksi kesalahan yang material dan kesalahan penyajian; b) Kemungkinan auditor akan melaporkan apa yang ditemukannya. Kedua hal tersebut mencerminkan terlaksana standar umum.

c. Independensi. Kepercayaan masyarakat umum atas independensi sikap auditor sangat penting bagi perkembangan profesi akuntan publik. Sikap independensi bermakna bahwa auditor tidak mudah dipengaruhi, sehingga auditor akan melaporkan apa yang ditemukannya selama proses pelaksanaan.

d. Sikap hati-hati Auditor yang bekerja dengan sikap hati-hati akan bekerja dengan cermat dan teliti sehingga menghasilkan audit yang baik. Hal ini mengandung arti bahwa auditor rmempunyai kewajiban untuk melaksanakan jasa profesionalnya dengan sebaik-baiknya sesuai dengan kemampuannya. Kesalahan dapat dideteksi jika auditor memiliki keahlian dan kecermatan.

e. Komitmen yang terhadap kualitas audit Komitmen dapat didefinisikan sebagai a) Sebuah kepercayaan pada dan penerimaan terhadap tujuan-tujuan dari nilai organisasi dan atau profesi; b) Sebuah kemauan untuk menggunakan usaha yang sungguh guna kepentingan organisasi atau profesi; c) Sebuah keinginan untuk memelihara keanggotaan dalam organisasi dan atau profesi.

f. Melakukan pekerjaan lapangan dengan tepat. Dalam melaksanakan tugasnya, seorang auditor harus berpedoman pada Standar Pemeriksaan Keuangan Negara (SPKN) yang ditetapkan oleh Badan Pemeriksa Keuangan (BPK). SPKN yang dibagi dalam Standar Umum, Standar Pelaksanaan, dan Standar Pelaporan.

\section{Pengetahuan Audit}

Pengetahuan audit diartikan dengan tingkat pemahaman auditor terhadap sebuah pekerjaan, secara konseptual atau teoritis. Menurut Brown dan Stanner (1983), perbedaan pengetahuan di antara auditor akan berpengaruh terhadap cara auditor menyelesaikan sebuah pekerjaan. Lebih lanjut dijelaskan bahwa seorang auditor akan bisa menyelesaikan sebuah pekerjaan secara efektif jika didukung dengan pengetahuan yang dimilikinya. Kesalahan diartikan dengan seberapa banyak perbedaan (deviasi) antara kebijakan-kebijakan perusahaan tentang pencatatan akuntansi dengan kriteria yang telah distandarkan. Dalam mendeteksi sebuah kesalahan, seorang auditor harus didukung dengan pengetahuan tentang apa dan bagaimana kesalahan tersebut terjadi (Tubbs, 2014). Cloyd (1997) menemukan bahwa besarnya usaha (proksi dari variabel akuntabilitas) yang dicurahkan seseorang untuk menyelesaikan sebuah pekerjaan berbeda-beda sesuai dengan tingkat pengetahuan yang dimiliki. Cloyd (1997) juga menemukan bahwa 
tingkat pengetahuan seseorang dapat meningkatkan kualitas hasil kerja. (Spilker, 1995) mengungkapkan bahwa karakteristik sebuah pekerjaan seperti tingkat kerumitan dan jumlah informasi yang disajikan/tersedia mempengaruhi hubungan pengetahuan, akuntabilitas dan kualitas hasil kerja. Pada pekerjaan yang lebih sederhana faktor usaha dapat menggantikan tingkat pengetahuan yang dimiliki seseorang (bersifat subsitusi) dan pengetahuan memiliki hubungan yang positif terhadap kualitas hasil kerja. Sedangkan untuk pekerjaan yang lebih rumit, akuntabilitas tidak lagi bersifat subsitusi dengan pengetahuan yang dimiliki seseorang.

\section{Pengalaman Kerja}

Sesuai dengan standar umum dalam Standar Profesional Akuntan Publik bahwa auditor disyaratkan memiliki pengalaman kerja yang cukup dalam profesi yang ditekuninya, serta dituntut untuk memenuhi kualifikasi teknis dan berpengalaman dalam bidang industri yang digeluti kliennya (Arens dan James, 2000). Pengalaman akuntan publik akan terus meningkat seiring dengan makin banyaknya audit yang dilakukan serta kompleksitas transaksi keuangan perusahaan yang diaudit sehingga akan menambah dan memperluas pengetahuannya di bidang akuntansi dan auditing (Christiawan, 2002).

\section{Gender}

Gender sering diidentifikasikan dengan jenis kelamin (sex), padahal gender berbeda dengan jenis kelamin. Secara umum jenis kelamin digunakan untuk mengidentifikasi perbedaan laki-laki dan perempuan dari segi anatomi biologis, sedangkan gender lebih mengarah kepada aspek sosial, budaya dan aspek nonbiologis lainnya. Kata gender berasal dari bahasa inggris yang berarti jenis kelamin. Gender dapat diartikan sebagai pembeda peran antara laki-laki dan wanita yang tidak hanya mengacu pada perbedaan biologis atau seksualnya, tetapi juga mencakup nilai-nilai sosial budaya (Zulaikha et al. 2006).

Gender dapat dilihat pada 2 karakter:

a. Feminin

Feminin dianggap khas perempuan, feminin diartikan sebagai sesuatu yang memiliki sifat-sifat keperempuanan.
Misalnya lembut, perasa, muda menangis, boneka, pegawai perpustakaan, sekretaris, aerobik, perawatan wajah adalah hal-hal yang dinilai feminin.

b. Maskulin

Maskulin dianggap khas laki-laki, maskulin diartikan sebagai sesuatu yang memiliki sifat kejantanan, baik berupa kepribadian, perilaku, pekerjaan, benda atau lainnya. Misalnya agresif, dominan, ambisius, tanpa emosi, balap motor, naik motor besar, senjata api, tinju, binaraga, buruh bangunan, sopir truk adalah hal-hal yang dianggap maskulin.

\section{Pengaruh Pengetahuan audit, pengalaman dan gender terhadap kualitas audit}

Cloyd (1997) menemukan bahwa besarnya usaha (proksi dari variabel akuntabilitas) yang dicurahkan seseorang untuk menyelesaikan sebuah pekerjaan berbeda-beda sesuai dengan tingkat pengetahuan yang dimiliki. Cloyd (1997) juga menemukan bahwa tingkat pengetahuan seseorang dapat meningkatkan kualitas hasil kerja. Spilker (1995) mengungkapkan bahwa karakteristik sebuah pekerjaan seperti tingkat kerumitan dan jumlah informasi yang disajikan/tersedia mempengaruhi hubungan pengetahuan, akuntabilitas dan kualitas hasil kerja. Sesuai dengan standar umum dalam Standar Profesional Akuntan Publik bahwa auditor disyaratkan memiliki pengalaman kerja yang cukup dalam profesi yang ditekuninya, serta dituntut untuk memenuhi kualifikasi teknis dan berpengalaman dalam bidang industri yang digeluti kliennya (Arens dan James, 2000). Hal tersebut mengindikasikan bahwa semakin lama masa kerja dan pengalaman yang dimiliki auditor maka akan semakin baik dan meningkat pula kualitas audit yang dihasilkan (Alim et al, 2007). Sedangkan dalam aspek gender, adanya stereotip bahwa pria memiliki karakter maskulin dan wanita memiliki karakter feminin telah menjadi salah satu dasar pemikiran penelitian bahwa terdapat perbedaan antara auditor pria dan wanita dalam beberapa aspek seperti kinerja, kepuasan kerja, kemajuan karir, dan aspek-aspek lain yang berkaitan dengan kantor akuntan publik. 
Ha1 : Pengetahuan audit, pengalaman kerja dan gender berpengaruh secara simultan terhadap kualitas audit

\section{Pengaruh Pengetahuan Audit terhadap Kualitas Audit.}

Perbedaan pengetahuan di antara auditor akan berpengaruh terhadap cara auditor menyelesaikan sebuah pekerjaan. Lebih lanjut dijelaskan bahwa seorang auditor akan bisa menyelesaikan pekerjaan secara efektif jika didukung dengan pengetahuan yang dimilikinya. Hartinto (2004) menemukan bahwa pengetahuan akan mempengaruhi keahlian audit yang pada gilirannya akan menentukan kualitas audit.

$\mathrm{Ha} 2$ : Pengetahuan audit berpengaruh positif terhadap kualitas audit

\section{Pengaruh Pengalaman Kerja terhadap Kualitas Audit.}

Sebagian besar orang memahami bahwa semakin banyak jam terbang seorang auditor, tentu dapat memberikan kualitas audit yang lebih baik dibandingkan dengan auditor yang memiliki jam terbang lebih sedikit atau auditor yang baru memulai karirnya. Dengan kata lain dapat dikatakan bahwa auditor yang berpengalaman dapat memberikan kualitas audit yang lebih baik dibandingkan dengan auditor yang belum pengalaman. Riset Herliansyah dan Ilyas (2006) menyimpulkan, pengalaman bermanfaat untuk meningkatkan kinerja dalam pengambilan keputusan.

Ha3 : Pengalaman kerja berpengaruh positif terhadap kualitas audit

Pengaruh Gender terhadap Kualitas Audit.

Bila wanita dapat berkarakter maskulin, maka sebaliknya, pria pun juga dapat berkarakter feminin. Penelitian Maupin dan Lehman (1994) menunjukkan bahwa auditor pria pada level junior, senior, dan manajer ada yang memiliki karakter feminin. Sementara itu, pada level partner baik pria dan wanta tidak ada yang memiliki karakter feminin (maskulin rendah-feminin tinggi). Dari hasil penelitian tersebut dapat disimpulkan bahwa semakin tinggi kesuksesan seseorang (baik pria maupun wanita) di kantor akuntan publik, maka semakin tinggi nilai-nilai maskulin yang melekat dalam dirinya. Jadi dapat dikatakan bahwa gender yang dilihat dari sisi maskulin dan feminin dapat mempengaruhi hasil kualitas audit. Auditor maskulin biasanya lebih agresif atau terburuburu dalam menyelesaikan tugas pekerjaannya sehingga tidak menggunakan seluruh informasi yang tersedia sehingga keputusan yang diambil kurang mewakili. Berbeda dengan auditor feminin, dalam mengambil suatu keputusan mereka tidak terlalu agresif cenderung lebih teliti dengan menggunakan seluruh informasi yang ada dan mengevaluasi kembali informasi tersebut.

Ha4.1 : Kepribadian feminin berpengaruh positif terhadap kualitas audit

Ha4.2 : Kepribadian maskulin berpengaruh negatif terhadap kualitas audit

\section{Metode Penelitian \\ Populasi dan Sampel}

Populasi dalam penelitian ini adalah auditor senior yang bekerja di kantor akuntan publik di Jakarta Barat. Populasi diambil sebanyak 19 kantor, dengan jumlah populasi 95 auditor. Penentuan sampel ini dilakukan dengan cara purposive sampling, yaitu populasi yang akan dijadikan sampel penelitian ini adalah memenuhi kriteria telah bekerja selama minimal satu tahun pada KAP. Dari 19 KAP di Jakarta Barat tersebut, didapatkan jumlah sampel sebanyak 77 auditor yang memenuhi kriteria tersebut.

\section{Metode Pengumpulan Data}

Pengumpulan data dalam penelitian ini dilakukan dengan cara memberikan pertanyaan tertutup kepada responden. Kuisioner penelitian disusun berdasarkan definisi operasional variabel. Skala pengukuran kuesioner dalam penelitian ini dibuat dalam bentuk skala likert. Dalam setiap pernyataan disediakan 5 jawaban dengan skor 1-5, yaitu jawaban Sangat Setuju (SS), dan Setuju (S), Kurang Setuju (KS), Tidak Setuju (TS), dan Sangat Tidak Setuju (STS)

\section{Definisi Operasional Variabel}

Dalam penelitian ini, variabel independen adalah:

a. Pengetahuan Audit (X1)

Pengetahuan audit adalah tingkat pemahaman auditor terhadap sebuah pekerjaan secara konseptual atau teorits.

b. Pengalaman Kerja (X2) 
Pengalaman adalah keterampilan dan pengetahuan yang diperoleh seseorang setelah mengerjakan sesuatu hal. Variabel pengalaman akan diukur menggunakan indikator lamanya bekerja, frekuensi pekerjaan pemeriksaan, dan lainnya.

c. Gender (X3 dan X4)

Gender merupakan salah satu faktor non teknis yang berpengaruh terhadap kualitas audit. Menurut Mikklola (2005) Gender didefinisikan sebagai suatu gambaran sifat, sikap dan perilaku pada auditor yang dibedakan atas tipe maskulin dan feminin. Feminin memiliki karakteristik seperti hangat dalam hubungan interpersonal, suka berafiliasi, kompromistik, sensitif, perasa, senang pada kehidupan kelompok sedangkan maskulin memiliki karakteristik kurang dapat mengekspresikan kehangatan, kurang responsive, suka mengambil resiko.

d. Variabel Dependen $(Y)$

Kualitas audit adalah sikap auditor dalam melaksanakan tugasnya yang tercermin dalam hasil pemeriksaannya yang dapat diandalkan sesuai dengan standar yang berlaku. Pada operasionalisasi variabel, peneliti mengidentifikasi dimensi dan indikator setiap variabel yang diukur.

\section{Metode Analisis Data}

\section{a. Uji Kualitas Instrumen}

\section{(1) Uji Validitas}

Uji validitas digunakan untuk mengukur sah atau valid tidaknya suatu kuesioner. Jika koefisien relasi ( $r$ ) bernilai positif dan lebih besar dari $r_{\text {tabel, }}$ maka dapat disimpulkan bahwa semua indikator sah atau valid. Begitu pula sebaliknya, jika bernilai positif atau negatif namun lebih kecil dari $r_{\text {tabel, }}$ maka butir pertanyaan dinyatakan invalid dan harus dihapus.

\section{(2)Uji Reliabilitas}

Setelah dilakukan uji validitas kemudian pertanyaan tersebut diuji dengan uji reliabilitas atau konsistensi internal yang bertujuan untuk mengetahui sejauh mana pengukuran yang telah dilakukan dalam penelitian ini dapat dipercaya atau diandalkan. Alat yang digunakan untuk menguji reeliabilitas adalah
Cronbach Alpha, dengan nilai minimal 0.7.

\section{b. Statistik Deskriptif Variabel}

Bahasannya statistik deskriptif dalam penelitian ini mencakup: 1) Distribusi frekuensi beserta bagian-bagiannya seperti, 2) Ukuran nilai pusat yaitu rata-rata.

\section{c. Uji Normalitas}

Uji normalitas digunakan untuk menguji apakah dalam model regresi variabel independen dan dependennya memiliki distribusi normal atau tidak. Uji kualitas data yang akan digunakan peneliti adalah uji normalitas Kolmogorov-Smirnov yaitu dengan membandingkan distribusi data (yang akan diuji normalitasnya) dengan distribusi normal baku. Seperti halnya uji normalitas, jika signifikansi $<0,05$ berarti data tidak berdistribusi normal, sebaliknya bila signifikansi $>0,05$ berarti data berdistribusi normal.

\section{d. Analisis Model Regresi}

Persamaan regresi berganda untuk pengujian hipotesis ini adalah :

$$
Y=\beta_{0}+\beta_{1} X_{1}+\beta_{2} X_{2}+\beta_{3} X_{3}+
$$

$\beta_{4} X_{4}+\varepsilon$

Dimana :

$$
\begin{array}{ll}
\mathrm{Y} & =\text { kualitas audit } \\
\beta_{0} & =\text { konstanta } \\
\beta_{1-4} & =\text { koefisien regresi } \\
\mathrm{X}_{1} & =\text { pengetahuan audit } \\
\mathrm{X}_{2} & =\text { pengalaman kerja } \\
\mathrm{X}_{3} & =\text { gender (kepribadian feminin) } \\
\mathrm{X}_{4} & =\text { gender (kepribadian maskulin) } \\
\varepsilon & =\text { error }
\end{array}
$$

\section{e. Uji Hipotesis}

Untuk menganalisis model diatas digunakan teknik regresi linier berganda. Selanjutnya dalam pengujian hipotesis akan digunakan uji $F$ untuk dan uji $t$, apakah variabel independen (pengetahuan audit, pengalaman kerja dan gender) secara simultan ataupun parsial berpengaruh terhadap variabel dependen (kualitas audit). Syarat dikatakan signifikan apabila angka signifikansi $<0.05$.

\section{Hasil Penelitian Dan Pembahasan Gambaran umum Data Responden}

Berikut ini adalah gambaran data pengumpulan data responden 
Tabel 1

Data Sampel Penelitian

\begin{tabular}{l|c|c}
\hline Keterangan & Akuntan & Prosentase \\
\hline Jumlah Kuesioner yang disebar & 77 & $100 \%$ \\
Jumlah Kuesioner yang kembali & 58 & $75 \%$ \\
Jumlah Kuesioner yang tidak & 19 & $25 \%$ \\
kembali & &
\end{tabular}

Dari tabel 1 tersebut di atas terlihat bahwa dari 77 kuesioner yang dibagikan kepada responden ternyata hanya 58 yang terisi penuh dan kembali. Selanjutnya 58 data ini yang diolah, karena telah memenuhi syarat sampel besar.

Sedangkan demografi responden adalah sebagai berikut :

Tabel 2

Data Demografi Responden

\begin{tabular}{|c|c|c|c|c|}
\hline Demografi & Kriteria & Jumlah & Prosentase & Total \\
\hline \multirow{4}{*}{ Usia } & $25-30$ & 35 & $60 \%$ & \\
\hline & $30-35$ & 11 & $19 \%$ & \\
\hline & $35-40$ & 10 & $17 \%$ & \\
\hline & $>40$ & 2 & $4 \%$ & \\
\hline Total & & 58 & & $100 \%$ \\
\hline \multirow[t]{2}{*}{ Jenis kelamin } & Pria & 31 & $53 \%$ & \\
\hline & Wanita & 27 & $47 \%$ & \\
\hline Total & & 58 & & $100 \%$ \\
\hline \multirow[t]{3}{*}{ Pendidikan } & S1 & 38 & $66 \%$ & \\
\hline & S2 & 19 & $32 \%$ & \\
\hline & S3 & 1 & $2 \%$ & \\
\hline Total & & 58 & & $100 \%$ \\
\hline \multirow[t]{3}{*}{ Lama Bekerja } & $\begin{array}{l}3-6 \\
\text { thn }\end{array}$ & 28 & $48 \%$ & \\
\hline & $\begin{array}{l}7-10 \\
\text { thn }\end{array}$ & 20 & $35 \%$ & \\
\hline & $>10$ thn & 10 & $17 \%$ & \\
\hline Total & & 58 & & $100 \%$ \\
\hline
\end{tabular}

Dari Tabel 2 di atas, maka dapat disimpulkan bahwa dilihat dari segi usia responden penelitian didominasi oleh usia dewasa awal. Jika dilihat dari jenis kelamin, dapat disimpulkan bahwa responden penelitian didominasi oleh pria. Jika dilihat dari pendidikan, didominasi oleh responden dengan jenjang pendidikan s1. Dan jika dilihat dari lama bekerja responden penelitian didominasi oleh responden dengan lama bekerja $3-6$ tahun.

\section{Statistik Deskriptif Variabel}

Berikut ini adalah data statistic deskriptif :

Tabel 3

Data Statistik deskriptif

Descriptive Statistics

\begin{tabular}{l|r|l}
\hline & \multicolumn{1}{|c|}{ N } & Mean \\
\hline Pengetahuan Audit & 58 & 3.9617 \\
PengalamanKerja & 58 & 4.0024 \\
Gender & 58 & 0.5862 \\
KualitasAudit & 58 & 3.9353 \\
Valid N (listwise) & 58 & \\
\hline \multicolumn{2}{c|}{ Dari table 3 tersebut di atas, }
\end{tabular}
pengetahuan audit memiliki nilai rata-rata sebesar 3.9617 artinya auditor di KAP Jakarta Barat memiliki pengetahuan audit yang tinggi. Hal tersebut dapat terjadi karena auditor telah meningkatkan pengetahuannya secara konsisten. Pengalaman kerja memiliki nilai ratarata sebesar 4.0024 artinya auditor-auditor di KAP Jakarta Barat memiliki banyak pengalaman audit. Hal tersebut dikarenakan jam terbang auditor yang tinggi dan telah banyak melakukan audit di berbagai jenis perusahaan. Gender memiliki nilai rata-rata sebesar 0,5862. Angka 1 menunjukkan jumlah feminin sebanyak 34 responden dengan persentase sebesar $58.6 \%$ dan angka 0 menunjukkan jumlah maskulin sebanyak 24 responden dengan persentase $41.4 \%$. Maka dapat disimpulkan bahwa auditor lebih cenderung memiliki sifat feminin. Hal tersebut akan terlihat pada saat auditor melakukan audit, mereka juga mempertimbangkan asumsi pribadi dalam mengambil keputusan. Sedangkan kualitas audit yang memiliki nilai rata-rata sebesar 3.9353 artinya bahwa auditor di KAP Jakarta Barat memiliki kualitas audit yang tinggi. Hal tersebut dikarenakan kualitas audit yang dicapai memiliki kompetensi yang baik dan dapat bersaing dengan KAP diluar Jakarta Barat. 
Berikut ini adalah data uji validitas data Tabel 4 penelitian :

Data Uji Validitas

\begin{tabular}{|c|c|c|c|c|c|c|c|}
\hline Item & r hit & Item & r hit & Item & r hit & Item & r hit \\
\hline penget1 & $\begin{array}{c}.891^{* *} \\
.000\end{array}$ & pengal1 & $\begin{array}{l}.897^{* *} \\
.000\end{array}$ & fem1 & $\begin{array}{c}.837^{* *} \\
.000\end{array}$ & maskul1 & $\begin{array}{l}.800^{* *} \\
.000\end{array}$ \\
\hline penget2 & $\begin{array}{l}.915^{* *} \\
.000\end{array}$ & pengal2 & $\begin{array}{l}.931^{* *} \\
.000\end{array}$ & fem2 & $\begin{array}{l}.888^{* *} \\
.000\end{array}$ & maskul2 & $\begin{array}{l}.915^{* *} \\
.000\end{array}$ \\
\hline penget3 & $\begin{array}{l}.906^{* *} \\
.000\end{array}$ & pengal3 & $\begin{array}{l}.929^{* *} \\
.000\end{array}$ & fem3 & $\begin{array}{l}.862^{* *} \\
.000\end{array}$ & maskul3 & $\begin{array}{l}.930^{* *} \\
.000\end{array}$ \\
\hline penget4 & $\begin{array}{l}.920^{* *} \\
.000\end{array}$ & pengal4 & $\begin{array}{l}.943^{* *} \\
.000\end{array}$ & fem4 & $\begin{array}{l}.818^{* *} \\
.000\end{array}$ & maskul4 & $\begin{array}{l}.841^{* *} \\
.000\end{array}$ \\
\hline penget5 & $\begin{array}{l}.909^{* *} \\
.000\end{array}$ & pengal5 & $\begin{array}{l}.920^{* *} \\
.000\end{array}$ & fem5 & $\begin{array}{l}.841^{* *} \\
.000\end{array}$ & maskul5 & $\begin{array}{l}.807^{* *} \\
.000\end{array}$ \\
\hline penget6 & $\begin{array}{l}.909^{* *} \\
.000\end{array}$ & pengal6 & $\begin{array}{l}.889^{* *} \\
.000\end{array}$ & fem6 & $\begin{array}{l}.675^{* *} \\
.000\end{array}$ & maskul6 & $\begin{array}{l}.244 \\
.065\end{array}$ \\
\hline penget7 & $\begin{array}{l}.869^{* *} \\
.000\end{array}$ & pengal7 & $\begin{array}{l}.932^{* *} \\
.000\end{array}$ & femtotal & 1 & maskul7 & $\begin{array}{l}.544^{* *} \\
.000\end{array}$ \\
\hline penget8 & $\begin{array}{l}.923^{* *} \\
.000\end{array}$ & pengaltotal & 1 & & & maskul8 & $\begin{array}{l}.833^{* *} \\
.000\end{array}$ \\
\hline penget9 & $\begin{array}{l}.924^{* *} \\
.000\end{array}$ & & & & & maskultotal & 1 \\
\hline pengettotal & 1 & & & & & & \\
\hline
\end{tabular}

Berdasarkan tabel 4 diatas dapat djelaskan bahwa variabel pengetahuan audit, pengalaman dan kepribadian feminine dan maskulin memiliki kriteria valid untuk setiap item pernyataan dengan menunjukan $r$ hitung $>r$ tabel, dimana $r$ table adalah sebesar 0,259. Hal ini berarti bahwa semua item pernyataan yang digunakan dalam penelitian ini mampu mengungkapkan sesuatu yang diukur pada kuesioner tersebut.

\section{Uji Reliabilitas}

Berikut ini adalah hasil uji reliabilitas data :

Tabel 5

Hasil Uji Reliabilitas

Reliability Statistics
\begin{tabular}{|c|c|}
\hline $\begin{array}{c}\text { Cronbach's } \\
\text { Alpha }\end{array}$ & $\begin{array}{c}\text { N of } \\
\text { Items }\end{array}$ \\
\hline .722 & 5 \\
\hline
\end{tabular}

Dari hasil analisis di atas, diperoleh koefisien reliabilitas Cronbach Alpha sebesar
0,722 . Dengan hasil tersebut maka bisa dikatakan bahwa data tersebut adalah reliabel, dengan Cronbach Alpha lebih besar dari 0,7.

\section{Uji Normalitas Data}

Tabel 6

Uji Normalitas Data

One-Sample Kolmogorov-Smirnov Test

\begin{tabular}{ll|r}
\hline & \multicolumn{2}{|c}{$\begin{array}{c}\text { Unstandardized } \\
\text { Residual }\end{array}$} \\
\hline $\mathrm{N}$ & 58 \\
Normal & Mean & .0000000 \\
Parameters ${ }^{\mathrm{a}, \mathrm{b}}$ & Std. Deviation & .24782567 \\
Most Extreme $\quad$ Absolute & .104 \\
Differences $\quad$ Positive & Negative & .104 \\
& -.101 \\
Kolmogorov-Smirnov Z & .793 \\
Asymp. Sig. (2-tailed) & .555 \\
a. Test distribution is Normal. & \\
b. Calculated from data. &
\end{tabular}


Dari table 6 di atas, uji normalitas yang ditunjukkan dengan uji One Sample Kolmogorov-Smirnov, terlihat bahwa nilai asymp sig 0,555 > 0,05 maka data dikatakan normal. Dengan demikian, berdasarkan hasil pengujian normalitas data terbukti bahwa data dalam penelitian ini berdistribusi normal.

\section{Uji Hipotesis}

Tabel 7

Uji F dan t

\begin{tabular}{l|l|r}
\hline & \multicolumn{1}{|c|}{ Variabel } & F Hitung \\
\hline Uji F & 158.659 \\
Uji t & $\begin{array}{l}\text { Pengetahuan Audit } \\
\text { Pengalaman } \\
\text { Kepribadian Feminin } \\
\text { Kepribadian Maskulin } \\
\text { Konstanta }\end{array}$ & \\
\hline
\end{tabular}

Dilihat dari table 5 tersebut di atas, hasil uji F pada tabel 5.14 menunjukkan nilai F-test dengan probabilitas (tingkat signifikansi) 0,000 lebih kecil dari 0,050 . Sehingga dari hasil yang diperoleh dapat dikatakan bahwa $\mathrm{Ha} 1$ diterima atau terdapat pengaruh simultan antara pengetahuan audit, pengalaman dan perspektif peminin dan maskulin terhadap kualitas audit. Sedangkan dari uji t diperoleh fakta bahwa $\mathrm{Ha} 2$ diterima atau pengetahuan audit berpengaruh positif terhadap kualitas audit dengan angka signifikansi sebesar $0.000<0.050$. Variabel pengalaman audit tidak berpengaruh terhadap kualitas audit atau $\mathrm{Ha} 3$ ditolak dengan angka signifikansi sebesar $0.118>0.050$. Kepribadian feminin berpengaruh negatif terhadap kualitas audit, dengan angka signifikasnsi sebesar $0.007<0.050$ sehingga Ha4.1 diterima. Yang terakhir kepribadian maskulin tidak berpengaruh terhadap kualitas audit dengan tingkat signifikansi sebesar 0.569 atau Ha4.2 ditolak.

Pengetahuan audit memiliki pengaruh yang signifikan terhadap kualitas audit karena auditor di KAP Jakarta Barat memahami pengetahuan tentang akuntansi untuk membantu dalam mengolah data, mengolah angka, memahami aturan mengenai auditing sesuai dengan Standar Profesi Akuntan Publik, mengetahui isu-isu akuntansi yang paling baru, sebagai pengetahuan bagi auditor, memahami proses bisnis klien, tahu mengenai perkembangan teknik akuntansi terbaru, mengikuti seminar pelatihan-pelatihan akuntansi, mengetahui berbagai macam industri khusus, mengetahui proses bisnis umum lainnya selain entitas yang diperiksa sehingga hasil audit dapat digunakan untuk memenuhi kebutuhan para pemakai informasi keuangan. Dengan pengetahuan tersebut maka akan semakin besar probabilitas seorang auditor untuk menemukan dan melaporkan tentang adanya suatu pelanggaran dalam sistem akuhtansi kliennya.

Koefisienal amanSigaudit tidak berpengaruh terhadap kualitag.QQPRdit. Hal ini menunjukkan bahWa746engalarAaP00kerja tidak menentukan kualQtab86y dit kaßehb8ada kemungkinan semua audito26R KAP JaRk畞 Barat tidak mendasarkan diri-

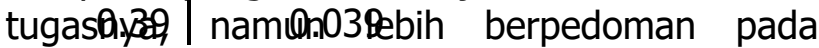
standar pemeriksaan yang diketahui.

Kepribadian feminin pada auditor berpengaruh negatif terhadap kualitas audit, yang artinya semakin feminin seorang auditor maka akan semakin menurunkan kualitas kerjanya sebagai seorang auditor. Hal ini mungkin terjadi karena dalam diri seorang yang berkepribadian feminin mengedepankan sikap sangat subyektif, emosional, tidak logis dan tidak percaya diri, sehingga dapat mempengaruhi pola pengambilan keputusan dalam audit. Hal ini akan menyebabkan turunnya kualitas audit.

Sedangkan kepribadian maskulin tidak berpengaruh terhadap kualitas audit dimungkinkan karena sifat yang paling menonjol dalam kepribadian maskulin adalah sifat logis. Auditor yang bersikap logis dalam pekerjaannya tidak akan mempengaruhinya dalam pengambilan keputusan atas temuan audit pada pelaksanaan pemeriksaan sehingga tidak mempengaruhi kualitas auditnya.

\section{Analisis Model Regresi \\ Persamaan regresi dalam penelitian ini mengacu pada tabel $\mathbf{5}$ tersebut di atas \\ $Y=0,39+0,764 X_{1}+0,186 X_{2}-0,262 X_{3}$ $0,059 X_{4}$}

Konstanta sebesar 0,39 artinya jika tidak ada variabel pengetahuan audit, pengalaman, dan kepribadian feminin dan maskulin maka nilai kualitas audit adalah sebesar 0,39. Pengetahuan audit memiliki koefisien regresi 
sebesar 0,764 menyatakan setiap kenaikan pengetahuan audit sebesar 1 nilai maka kualitas audit naik sebesar 0,764. Pengalaman kerja memiliki koefisien regresi sebesar 0,186 menyatakan setiap kenaikan pengalaman kerja sebesar 1 nilai maka kualitas audit naik sebesar 0,186. Kepribadian feminin memiliki koefisien regresi sebesar -0,262 menyatakan setiap kenaikan kepribadian feminin sebesar 1 nilai maka, kualitas audit turun sebesar 0,262. Kepribadian maskulin memiliki koefisien regresi sebesar -0,059 menyatakan setiap kenaikan kepribadian feminin sebesar 1 nilai maka, kualitas audit turun sebesar 0,059.

\section{Uji Koefisien Determinasi}

Tabel 8

Koefisien Determinasi

Model Summary ${ }^{b}$

\begin{tabular}{r|c|c|c|c}
\hline Model & $\mathrm{R}$ & $\begin{array}{c}\mathrm{R} \\
\text { Square }\end{array}$ & $\begin{array}{c}\text { Adjusted } \\
\mathrm{R} \\
\text { Square }\end{array}$ & $\begin{array}{c}\text { Std. } \\
\text { Error of } \\
\text { the } \\
\text { Estimate } \\
1\end{array}$ \\
$.187^{\mathrm{a}}$ & 0.035 & 0.017 & 0.54705
\end{tabular}

a. Predictors: (Constant), pengetahuanaudit, pengalamankerja, gender

b. Dependent Variable: kualitasaudit

Berdasarkan hasil pengolahan data, nilai koefisien determinasi yang sudah disesuaikan (Adjusted R Square) adalah sebesar 0,017. Artinya $1,7 \%$ variabel dependen kualitas audit dijelaskan oleh variabel independen yang terdiri dari pengetahuan audit, pengalaman kerja dan kepribadian feminine dan maskulin. Sisanya sebesar $98,3 \%$ dijelaskan oleh variabel lain diluar variabel yang digunakan.

\section{Kesimpulan Implikasi Dan Keterbatasan}

Penelitian ini menghasilkan suatu kesimpulan bahwa secara simultan pengetahuan audit, pengalaman kerja dan kepribadian feminin dan maskulin secara bersama-sama berpengaruh terhadap kualitas audit di Kantor Akuntan Publik Jakarta Barat. Berdasarkan hasil pengolahan data secara parsial menunjukan bahwa variabel pengetahuan audit berpengaruh terhadap kualitas audit, pengalaman kerja tidak mempunyai pengaruh yang signifikan terhadap kualitas audit. Sedangkan variabel kepribadian feminin berpengaruh negatif terhadap kualitas audit. Penelitian ini masih banyak kekurangan, antara lain belum menjelaskan dinamika psikologis keterkaitan antara kepribadian feminin terhadap terbentuknya kualitas audit. Bagi penelitian selanjutnya diharapkan dalam melakukan penelitian selanjutnya agar memperluas wilayah sampel dan dalam penelitian selanjutnya juga diharapkan bisa menambahkan variabel lain yang diduga memperngaruhi kualitas audit. Selain itu diharapkan penelitian selanjutnya melakukan analisis lebih mendalam terkait dengan factor psikologis dalam diri audit yang berpengaruh terhadap kualitas dalam bekerja.

\section{DAFTAR PUSTAKA}

Alim, M. N., Hapsari, T., \& Purwanti, L. (2007). Pengaruh Kompetensi Dan Independensi Terhadap Kualitas Audit Dengan Etika Auditor Sebagai Variabel Moderasi. Simposium Nasional Akuntansi X, 1-26. Makassar.

Arens, A. A., \& James, K. L. (2000). Auditing An Integrated Approach (8th Ed.). New Jersey: Prentice Hall International, Inc.

Bawono, I. R. (2010). Faktor - Faktor Dalam Diri Auditor Dan Kualitas Audit: Studi Pada Kap Big Four Di Indonesia. Jaai, Vol. 14.

Bem, S. L. (1974). The Measurement of Psychological Androgyny 1. 42(2).

Brown \& Stanner. (1983). The Assessment And Modification Of Concept Interrelationships. Journal Of Experimental Education, Vol 52, Page 11-21.

Brown, \& Stanner. (1983). The Assessment And Modification Of Concept Interrelationships. Journal Of Experimental Education. Journal of Experimental Education, Vol. 52, Page $11-21$.

Christiawan, Y. J. (2002). Kompetensi Dan 
Independensi Akuntan Publik: Refleksi Hasil Penelitian Empiris. Jurnal Akuntansi \& Keuangan, 4, 79-92.

Cloyd, C. B. (1997). Performance In Reseach Task: The Joint Effect Of Knowledge And Accountability. 72(1), 111-131.

Deangelo, L. E. (1981). Auditor Independence, "Low Balling", And Disclosure Regulation. 3, 113-127.

Fortuna Sari, N., \& Ramantha, I. (2015). Pengaruh Sikap Skeptisme, Pengalaman Audit, Kompetensi, Dan Independensi Auditor Pada Kualitas Audit. E-Jurnal Akuntansi, 11(2), 470-482.

Futri Dan Juliarsa. (2015). Pengaruh Independensi, Profesionalisme, Tingkat Pendidikan, Etika Profesi, Pengalaman Dan Kepuasan Kerja Auditor Pada Kualitas Audit Kantor Akuntan Publik Di Bali. E-Jurnal Akuntansi, (Universitas Udayana), 444-461.

Hartinto. (2004a). Pengaruh Keahlian Dan Independensi Terhadap Kualitas Audit Studi Empiris Pada Kap Di Jawa Timur.

Hartinto, T. (2004b). Pengaruh Keahlian Dan Independensi Terhadap Kualitas Audit Studi Empiris Pada Kap Di Jawa Timur.

Harvita, Y. A., \& Pramudji, S. (2012). Pengaruh Pengalaman Kerja, Independensi, Obyektifitas, Integritas, Dan Kompetensi Terhadap Kualitas Hasil Audit. Diponogoro Journal Of Accounting, 1, 110.

Haryono, Y. A. L. (2001). Dasar-Dasar Akuntansi. Yogyakarta: Stie Ykpn.

Herawaty, A., \& Sutanto, Y. K. (2009). Pengaruh Profesionalisme, Pengetahuan Mendeteksi Kekeliruan, Dan Etika Profesi Terhadap Pertimbangan Tingkat Materialitas Akuntan Publik. 11, 13-20.

Herliansyah, Y., \& Ilyas, M. (2006). Pengaruh Pengalaman Auditor Terhadap
Penggunaan Bukti Tidak Relevan Dalam Auditor Judgment. 23-26.

Imron, M. A., Widyastuti, T., \& Amilin. (2017). Pengaruh Pengetahuan Audit Independensi Dan Audit Investigasi Pada Auditor Inspektorat Jenderal Kementerian Keuangan. Jurnal IImiah Widya Ekonomika, 1(July), 1-8.

Iskandar Dan Indarto. (2015). Interaksi Independensi, Pengalaman, Pengetahuan, Due Professional Care, Akuntabilitas Dan Kepuasan Kerja Terhadap Kualitas Audit. Jurnal Ekonomi Dan Bisnis, Volume Xvi.

Jamilah, S., \& Fanani, Z. (2007). Pengaruh Gender, Tekanan Ketaatan, Dan Kompleksitas Tugas Terhadap Audit Judgment. 1-30.

Maupin, R. J., \& Lehman, C. R. (1994). Talking Heads: Stereotypes, Status, Sex-Roles And Satisfaction of Female And Male Auditors.

Meyers-Levy, J. (1986). Gender Difference In Information Processing: A Selectivity Interpretation.In Cognitive And Affective Response To Advertising (P. Calfferata \& A. M. Tybout, Eds.). Lexington.

Mikkola, A. (2005). Rule Of Gender Equality In Development. A Literature Review. Helsinki Center Of Economic Research, Vol. 84.

Salsabila \& Prayudiawan. (2011). Pengaruh Akuntabilitas, Pengetahuan Audit Dan Gender Terhadap Kualitas Hasil Kerja Auditor Internal (Studi Empiris Pada Inspektorat Wilayah Provinsi Dki Jakarta). Telaah Dan Riset Akuntansi, 4, 155-175.

Saripudin, Herawati, N., \& Rahayu. (2012). Pengaruh Independensi, Pengalaman, Due Professional Care Dan Akuntabilitas Terhadap Kualitas Audit. E-Jurnal Binar Akuntansi, Vol. 1(1). 
Spilker, B. C. (1995). The Effect Of Time Pressure And Knowledge On Key Word Selection Behavior In Tax Research. The Accounting Review, Vol. 70, Pages 4070.

Sukriah, I., Akram, \& Inapty, B. A. (2009). Pengaruh Pengalaman Kerja, Independensi, Obyektifitas, Integritas Dan Kompetensi Terhadap Kualitas Hasil Pemeriksaan. Simposium Nasional Akuntansi Xii. Palembang.

Tubbs, R. M. (2014). The On Effect of of Experience Organization Knowledge The And Auditor' $S$ Amount. 674), 783801.

Widagdo, R., Irawan, S. A., \& Lesmana, S. (2002). Analisis Pengaruh AtributAtribut Kualitas Audit Terhadap Kepuasan Klien ( Studi Empiris Pada Perusahaan Yang Terdaftar Di Bursa Efek Jakarta ). (September).

Zulaikha. (2006). Pengaruh Interaksi Gender, Kompleksitas Tugas Dan Pengalaman Auditor Terhadap Audit Judgment. Simposium Nasional Akuntansi IX. Padang. 